Jpn. J. Oral Biol., $27: 53-63,1985$.

\title{
培養線維芽細胞の増殖とコラゲン線維形成
}

\author{
松尾朗 矢嶋 俊彦 \\ 東日本学園大学歯学部口腔解剖学第 1 教室
}

〔受付 : 昭和59年 9 月 18 日]

\section{Cell proliferation and collagen fibrogenesis of cultured fibroblasts}

\author{
Akira Matsuo and Toshihiko Yajima \\ Department of Oral Anatomy, School of Dentistry, Higashi-Nippon-Gakuen \\ University, Ishikari-Tobetsu, Hokkaido, 061-02
}

[Received for publication September 18, 1984]

Key words : fibroblast / cell proliferation/ collgen fibrogenesis / ascorbic acid/diphenylhydantoin

\begin{abstract}
The effects of various concentrations of serum, ascorbic acid, and sodium diphenylhydantoin $(\mathrm{DPH})$ in culture medium on cell proliferation and collagen fibrogenesis were morphologically investigated in rat skin fibroblasts.

The cell proliferative rate appeared to be dependent upon the serum concentration both in $\alpha \mathrm{MEM}$ and DM-160 medium. But, the rate in $\alpha$ MEM medium was much higher than that in DM-160 medium. Fibroblasts in $\alpha$ MEM medium produced extracellular fibers stained positively by silver impregnation as early as 1 day after planting and accumulated collagen fibers in the intercellular matrix continuously throughout their logarithmic growth. This fibrogenesis was not affected by the serum concentration in the culture medium. The degree of fibrogenesis in DM-160 medium was less up to 3 weeks, and the amount of collagen in the cell layer increased thereafter.

Fibroblasts grown in DM-160 medium containing less than $1 \mu \mathrm{g} / \mathrm{m} l$ ascorbic acid showed evidence of ascorbic acid deficiency when compared with cells grown in $\alpha$ MEM medium containing $50 \mu \mathrm{g} / \mathrm{m} l$ ascorbic acid. Ultrastructural study demonstrated that ascorbic acid deficiency prevented the deposition of typical $64 \mathrm{~nm}$-banded collagen fibrils; instead, finer, unbanded fibrils and microfibrils were deposited extracellularly. These results indicate that the fibroblasts require ascorbic acid to produce collagen fibers.
\end{abstract}

Addition of DPH to cultured fibroblasts resulted in stimulation of their proliferation and en. hancement of collagen fibrogenesis.

\section{緒言}

培養線維芽細胞における細胞増殖とコラゲン生 成および線維形成に関しては，数多くの研究がな されてきている ${ }^{1-13)}$ 。その報告の多くで，線維芽 細胞のコラゲン分子の生成と分泌は，増殖対数期 を含む全発育相を通して認められるが，コラゲン 線維形成と蓄積は，定常期に入った後に行なわれ るとしている ${ }^{1,2)}$ 。増殖対数期の終りから定常期

北海道石狩郡当別町金沢 1757 (
に入ると，プロトコラゲンのプロリン水酸化酵素 とリジン水酸化酵素活性が急激に高まることが, 生化学的に明らかにされている(14)。このため, 細胞のコラゲンの生成と分泌が高まると共に，八 イドロオキシプロリン含量の多い，変性温度の高 い安定した不溶性コラゲンヘリックスが作ら れ ${ }^{15)}$, 線維形成がなされるものと考えられてい る。また，これらの水酸化酵素の活性化因子とし てアスコルビン酸が必要であり，アスコルビン酸 添加群では, 活発なコラゲン生成と線維形成が行 
なわれると報告されている ${ }^{3,8,10)}$ 。他方，アスコル ビン酸は培養液中では，分解変性してしまうこと も知られており，特にアスコルビン酸の線維形成 への作用については形態学的にも結果の一致をみ ていない。

また, 臨床的には, 抗痙攣剤のジフェニルヒダ ントイン (sodium diphenylhydantoin, DPH) の投与に伴う，歯肉でのコラゲン線維の過形成に よる歯肉肥大がしばしばみられる。その発症機序 は明らかではないが， 口腔内の局所因子が強く作 用しているとする考えが現在主流を占めている。 しかし，培養を用いた基礎的研究から，DPH が 線維芽細胞の代謝過程に直接的に働くとの推測も 報告されている16-19)。

そこで, 本研究では培養系を用いて, 線維芽細 胞の増殖とコラゲン線維形成に対する，培地，血 清濃度, アスコルビン酸と DPH の影響につい て, 形態学的に検討を試みた。

\section{材料および方法}

\section{1. 培養細胞と培地}

実験には，ラット背側皮膚の真皮に由来した線 維芽細胞系，RSF-1，を用いた。

培地は, $\alpha$-MEM 培地（アスコルビン酸含量 50 $\mu \mathrm{g} / \mathrm{m} l$, Flow Laboratories Inc., California, U.S.A.）DM-160培地（アスコルビン酸含量 $1 \mu \mathrm{g} /$ $\mathrm{m} l$, 極東, 東京) と Eagle の MEM 培地 ( スコルビン酸不含有, Flow Laboratories Inc.), および MEM 培地にアスコルビン酸 $(50 \mu \mathrm{g} / \mathrm{m} l$, 和光純薬，大阪）を添加したものを使用した。こ れらの培地に仔ウシ血清 (Armour Pharmacetical Co., Illinois, U.S.A.) を 1， 5，10\%加え培 養に用いた。

また，実験群の 1 つには，DPH（5，20，40, $100 \mu \mathrm{g} / \mathrm{m} l$ ) を添加した。DPH（アレビアチン®， 大日本製薬, 大阪）は, $0.1 \mathrm{M} \mathrm{NaOH}$ で希釈し たものを用い，対照群には $\mathrm{DPH}$ 添加量と等量 の0.1M NaOH を加えた。

\section{2 . 培養法}

線維芽細胞（6X10 cells/dish） は, $35 \mathrm{~mm} 7^{\circ}$ ラスチック培養シャーレ (Nunc, Roshilde, Denmark）に $5 \%$ 仔ウシ血清を添加した $\alpha$-MEM 培
地（ $\alpha$ MEM- $5 \%$ ）を加え，炭酸ガス培養器（5 $\% \mathrm{CO}_{2}-95 \%$ air, $\left.37^{\circ} \mathrm{C}\right)$ で培養された。細胞は, $\alpha \mathrm{MEM}-5 \%$ 培地で 24 時間培養後，各実験群の 培 羕液に交換され，実験が開始された。培養液は 3 日ごとに交換された。

\section{3.コラゲン線維形成の観察}

培養物はシャーレのまま $10 \%$ 中性ホルマリンで 固定後, Bielshowsky-Gömöri 渡銀染色を施し, 光顕にて、コラゲン線維形成を比較観察した。

また，一部試料では，同一部位で，Van Gieson 染色 (Hansen 改良法) と鉄コロイド染色 による酸性粘液多糖類の検出を行った。

さらに，グルタールとオスミック酸の二重固定 後，通法による電顕観察を合せて行なった。

\section{結 果}

1. 培地と血清濃度の影響

a. 細胞増殖

$\alpha$-MEM 培地における， 5 \%血清（ $\alpha$ MEM- 5 \%) と $10 \%$ 血清添加（ $\alpha$ MEM-10\%） 群での，そ れぞれの細胞増殖率は最初の 3 日間で 4.9 と 5.4 , 次の 3 日間で 1.5 と $2.1,6-9$ 日間で 1.4 と1.3で あった。細胞は培養 3-6 日まで対数的に増殖

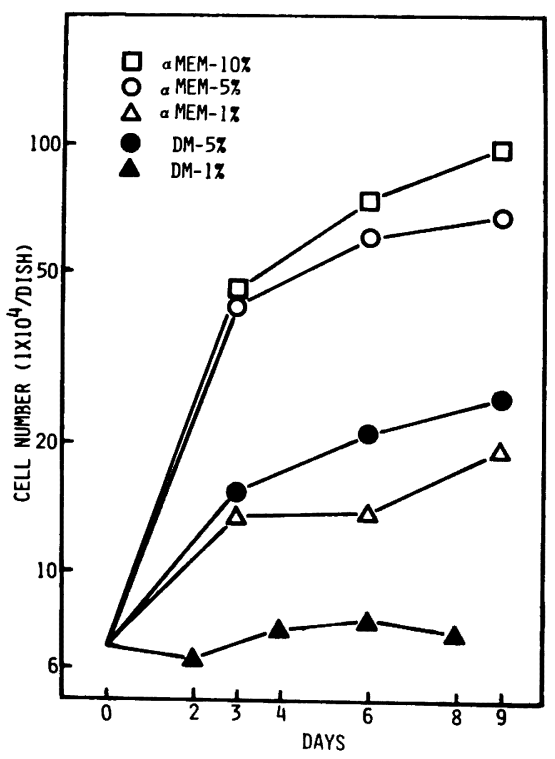

Fig. 1 Comparison of the proliferation rate of fibroblasts at various serum concentra. tions in $\alpha \mathrm{MEM}$ and DM-160 media. 
し，6日以降では増殖率は低下し，定常期に入っ たことを示した (Fig. 1)。1\%血清添加（ $\alpha$ MEM- $1 \%$ ）群では, その増殖曲線はやや異な り，培養 9 日間での増殖率は 2.9 あっった（Fig. 1)。

DM-160培地の $5 \%$ 血清添加（DM- $5 \%$ ）群で の細胞増殖率は最初の 3 日間で 2.3 , 次の 3 日間で 1.3，そして，6-9 日間で1.2であった（Fig. 1)。 増殖率は全体に低いが， $\alpha$ MEM- $5 \%, \alpha$ MEM-10 \%とほぼ同様な増殖曲線をえがいた。しかし，1 \%血清添加（DM-1\%）群では，培養 8 日間で増 殖は認められなかった。

b. 線維形成

$\alpha \mathrm{MEM}-5 \%$ では，培養24時間以内に渡銀され る細線維が， 細胞周囲にすでに形成されていた (Fig. 2a)。これらの線維は増殖対数期を通して 増加し，培養 9-14日の 定常期には培養シャーレ の全面で, 網目状線維シートを形成した（Fig. 2b)。しかし，DM-5\%では，培養14日まで渡銀 される線維はほとんど認められなかった

(Fig. 2c)。

$\alpha \mathrm{MEM}-5 \%$ で培養14日では，渡銀される線維

はVan Gieson 染色されなかったが，4 週間以 上培養したものではフクシン染色され，成熟コラ ゲン線維として観察された（Fig. 3a，c）。また， 同じ部位は鉄コロイド染色陽性であり，線維形成 と同時に多量の酸性粘液多糖類が形成されていた (Fig. 3b)。

$\alpha$ MEM-5 \%で活発に線維形成をしている線維 芽細胞は，やや拡張した粗面小胞体とょく発達し たゴルジ装置を有していた。細胞外には $64 \mathrm{~nm} の$ 横紋構造を有する多数のコラゲン原線維が観察さ
れた（Fig. 4a）。他方，DM-5\%で光顕的に線維 形成がほとんど認められない線維芽細胞では，拡 張した粗面小胞体はみられたが，ゴルジ装置は発 達していなかった。細胞外に横紋構造を有する線 維はごく少数しかみられなかったが，横紋構造の ない細線維と microfibrils の集合がしばしば観察 された (Fig. 4b)。

次にこのようなコラゲン線維形成状態をより定 量化して比較するため, 線維形成インデックス (histological fibrogenesis index, 0-5) を作成 した (Fig. 5)。

0 : 線維が全く形成されていない。

1 : 細い線維が一部の細胞周囲の みに形成さ れている。

2 : 細く，短かい線維が，ほとんど全ての細 胞周囲に形成されている。

$3:$ 線維が，シャーレ全体に粗な網状構造を 形成している。

4 : 線維が，シャーレ全体に密な網状構造を 形成している。

5 : 線維は, シャーレ全体に密で厚いシート 状構造を形成している。

$\alpha \mathrm{MEM}$ 培地では，増殖対数期（0-6日）を 通して index は上昇し，定常期に入る 6-9 日 で index 4 のプラトーに達した。培養 4 週間以 上のものでは index 5 を示すものもあった。培 養 1 日で $\alpha$ MEM- $5 \%$ と $\alpha$ MEM- $1 \%$ では index 2 の線維形成が認められたが， $\alpha \mathrm{MEM}-10 \%$ では index 1 であった (Fig. 6)。

DM- $5 \%$ では，培養 1 日でシャーレ当り数本の 線維が観察されたが，14日の培養期間を通し増加 せず，index 1 であった（Fig．6)。しかし，培

Fig. 2 Micrographs of fibroblast cultures stained by silver impregnation. a : 1-day-old culture in $\alpha$ MEM$5 \%$ medium, showing the localization of fibers on the cells. b : 9-day-old culture in $\alpha \mathrm{MEM}-5 \%$ medium, showing a tangle of fibers covering the cell layer. c: 14-day-old culture in DM-5\% medium, showing deeply stained nuclei and no fibers. a-c, $\times 150$.

Fig. 3 Results of three different stains of the same area of a fibroblast culture maintained in $\alpha \mathrm{MEM}-5 \%$ medium for 6 weeks. a : Van Gieson stain. b: Colloidal iron stain. c: Silver impregnation. Distribution of positively stained materials is identical with that of collagen fibers. a-c, $\times 150$.

Fig. 4 Electron micrographs of 9-day-old cultures. a : Fibroblast cultured in $\alpha$ MEM-5\% medium, showing highly developed rER and Golgi complex. Collagen fibrils with typical $64 \mathrm{~nm}$ cross-striation occupy the intercellular space. b: Fibroblast cultured in DM-5\% medium. Fine, unbanded fibrils and microfibrils constitute the extracellular matrix. $a$ and $b, \times 20,000$. 


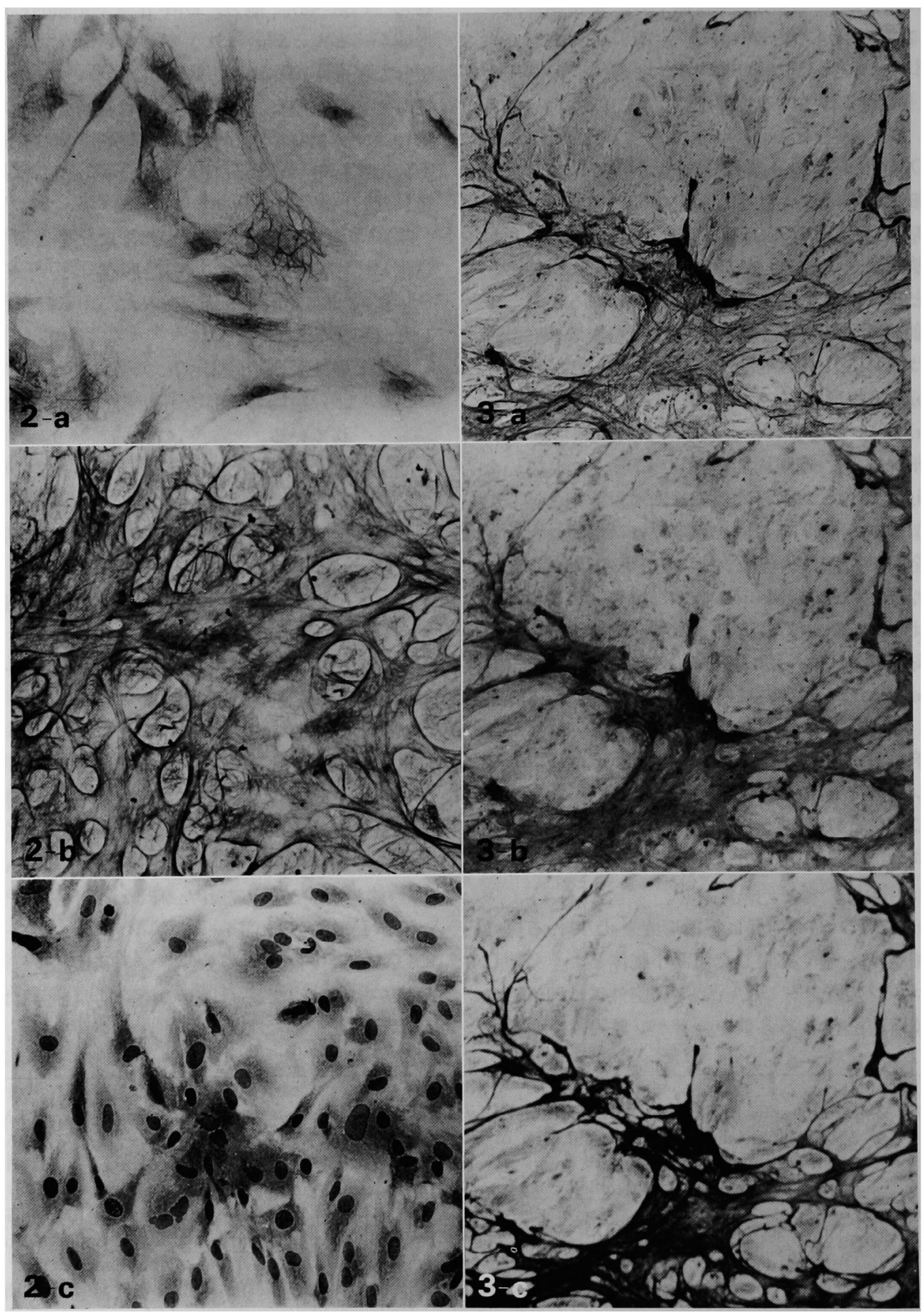




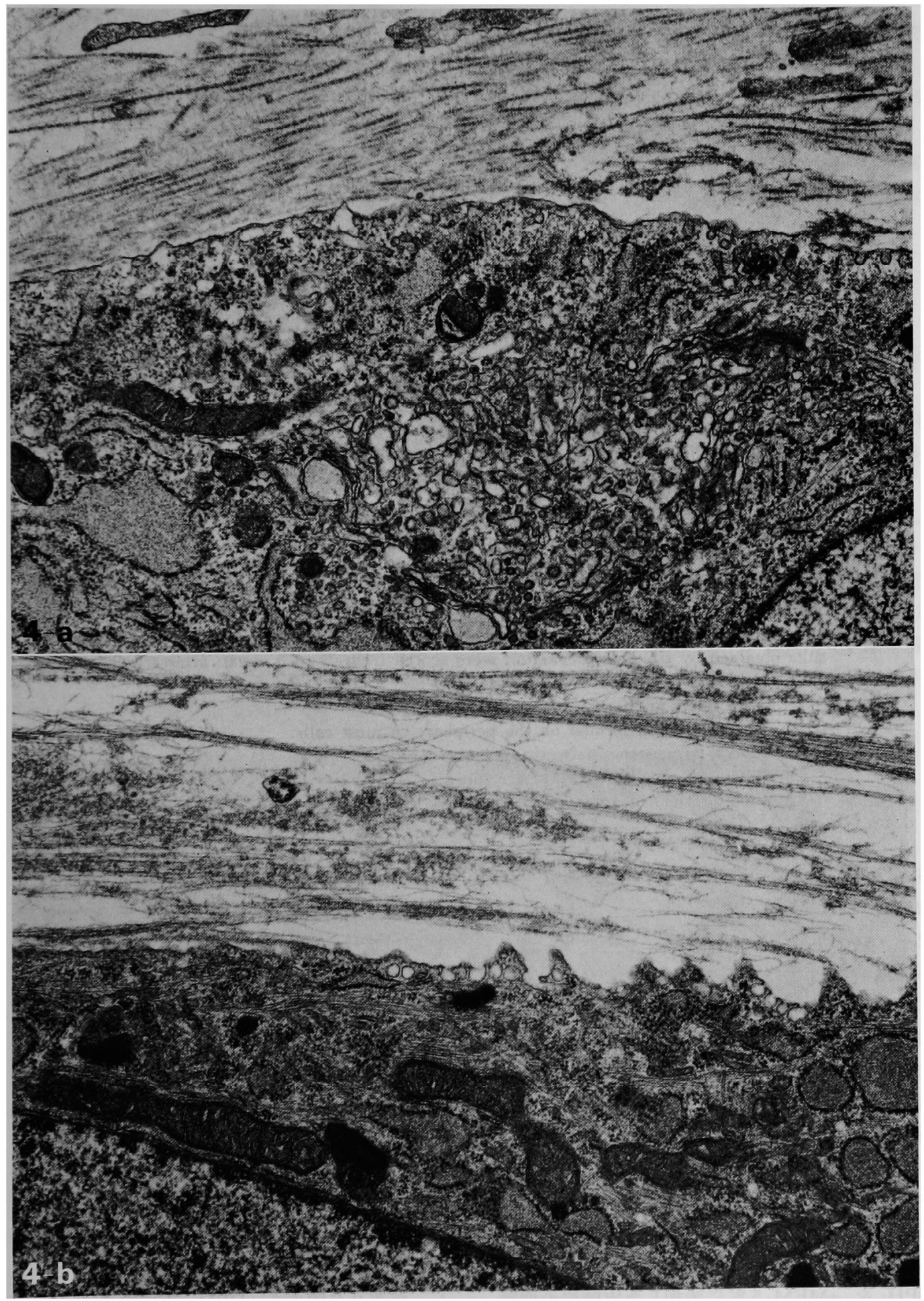




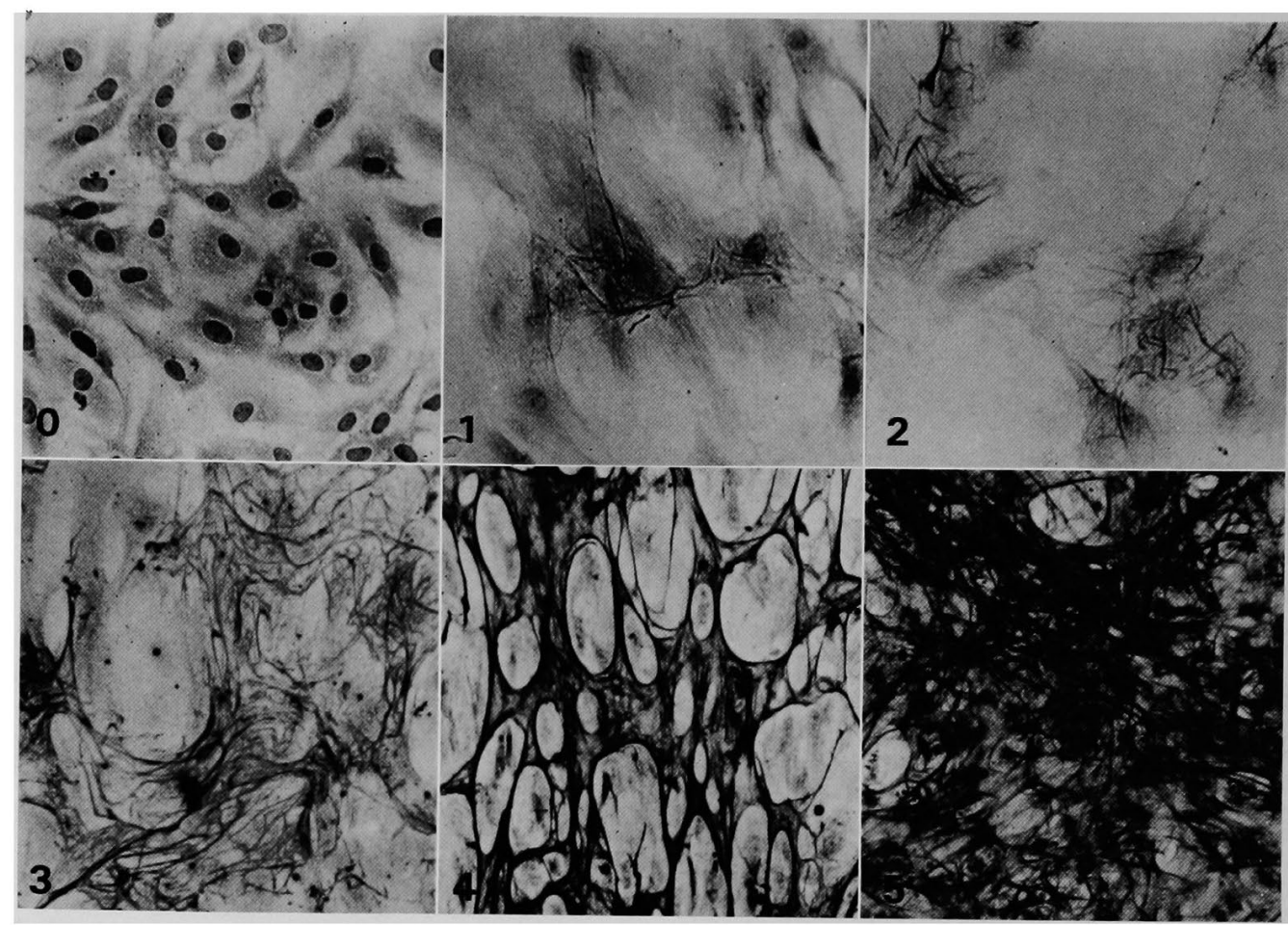

Fig. 5 Criteria for the scoring the histological fibrogenesis index of fibroblast cultures. The results obtained by silver impregnation were scored from 0 to 5 on an arbitrary scale.

0 : No fibers in culture.

1: Thin fibers are formed only in a limited area.

2: Thin fibers are formed on the periphery of most cells.

3: Fibers form coarse network structure.

4: Fibers form dense network structure.

5: Fibers form dense continuous sheet-like structure covering the whole culture.

養 3 週から線維が増加し， 2 カ月の長期培養では index 3-4の線維形成がみられた。

2.アスコルビン酸の影響

$5 \%$ 血清を加えたアスコルビン酸を全く含まな い Eagle の MEM 培地 (MEM-5\%) では, 培養14日間で渡銀される線維は全く認められなか った(Fig. 7a)。しかし，MEM-5\%にアスコルビ ン酸を $50 \mu \mathrm{g} / \mathrm{ml}$ 添加した群では，培養 1 日で線維 形成が認められた。線維形成 index は $\alpha \mathrm{MEM}$ $5 \%$ のそれとほぼ同様の経過を示し，培養 3 日で index 3，6 日で index 4 となった(Fig. 7b)。

3. $\mathrm{DPH}$ の影響

a. 細胞增殖

DPH を $\alpha$ MEM- $5 \%$ に添加した実験群の増殖 曲線は, DPH 無涯加の対照群とほぼ同様な経過
を示した。培垗 3-6日まで対数的増殖をし，そ れ以後増殖率は低下し, 定常期に入った（Fig. 8 )。DPH 濃度が $5-40 \mu \mathrm{g} / \mathrm{m} l$ では, 対照群 （ $\alpha$ MEM- $5 \% ）$ に比較し細胞増殖率はやや高く， 培養 9 日で対照群の約 1.5 倍となった。しかし， $\alpha \mathrm{MEM}-10 \%$ の増殖率を越えることはなかった。

DM- $5 \%$ DPH $(20 \mu \mathrm{g} / \mathrm{m} l)$ を添加したもの でも，培養 9 日で対照の約 1.5 倍の細胞増殖がみ られた。

b. 線維形成

$\mathrm{DPH}$ を $\alpha \mathrm{MEM}-5 \%$ \% $-40 \mu \mathrm{g} / \mathrm{ml}$ 添加した ものでは，その線維形成において，培養 6 日で対 照群との明確な差異は認められなかった。しか し, 培養 9 日頃から DPH 添加群で の線維形成 が高まり，14日では対照群（ $\alpha$ MEM- $5 \%$ ）と $\alpha$ - 


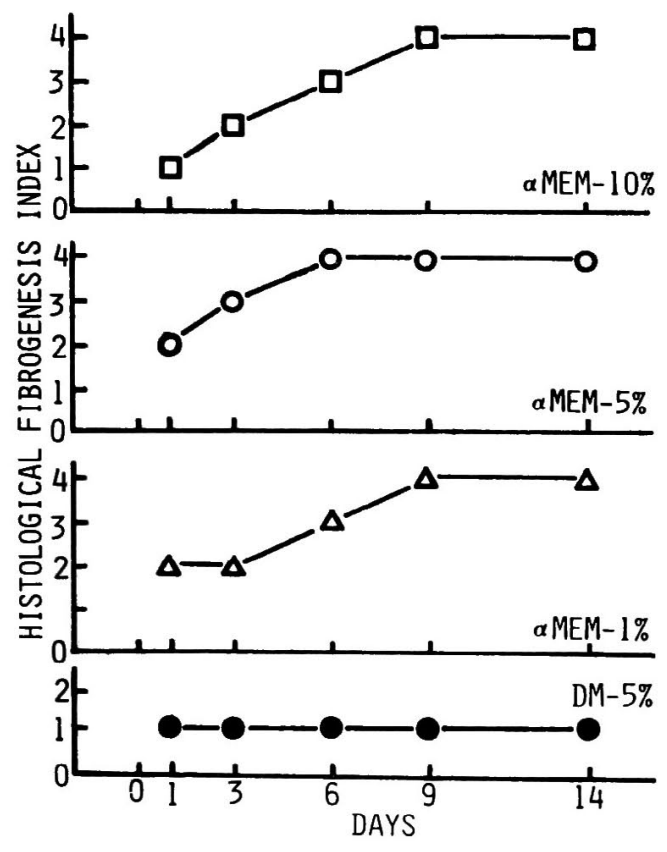

Fig. 6 Comparison of the time course of fibrogenesis by fibroblasts at various serum concentrations in $\alpha \mathrm{MEM}$ and DM-160 media (see Fig. 5 and text for description of the histological fibrogenesis index).
MEM-10\%の線維形成 index は 4であったのに 対して, DPH 添加群はシャーレ全面に均一で厚 い線維シートを形成しており index 5 であった (Fig. 9)。DPH $100 \mu \mathrm{g} / \mathrm{m} l$ の添加は, 線維形成 に拉いても，やや抑制的作用した。

また, DM- $5 \%$ への DPH $(20 \mu \mathrm{g} / \mathrm{m} l)$ 添加群 では，培養 9-14日間で線維形成作用を示さなか った。

\section{考 察}

1．培地と血清濃度の影響

細胞增殖率は， $50 \mu \mathrm{g} / \mathrm{ml}$ のアスコルビン酸を含 む $\alpha$-MEM 培地では血清濃度依存性を示し, 培 培盖 9 日で $5 \%$ と $10 \%$ 血清群は $1 \%$ 血清群の 3.4 倍 と4.9倍であった。一方, $1 \mu \mathrm{g} / \mathrm{m} l$ のアスコルビ ン酸を含む DM-160培地では， 5 \%血清群は $\alpha$ MEM の $1 \%$ 血清群に近い增殖率を示した。しか し， 1 \%血清群では細胞の増殖が みられなかっ た。DM-160培地は，アスコルビン酸を除く他の 組成分の多くは $\alpha$-MEM 培地と同等かそれ以上 に含有していることから，アスコルビン酸は線維 芽細胞の增殖に対して直接または間接的に作用し

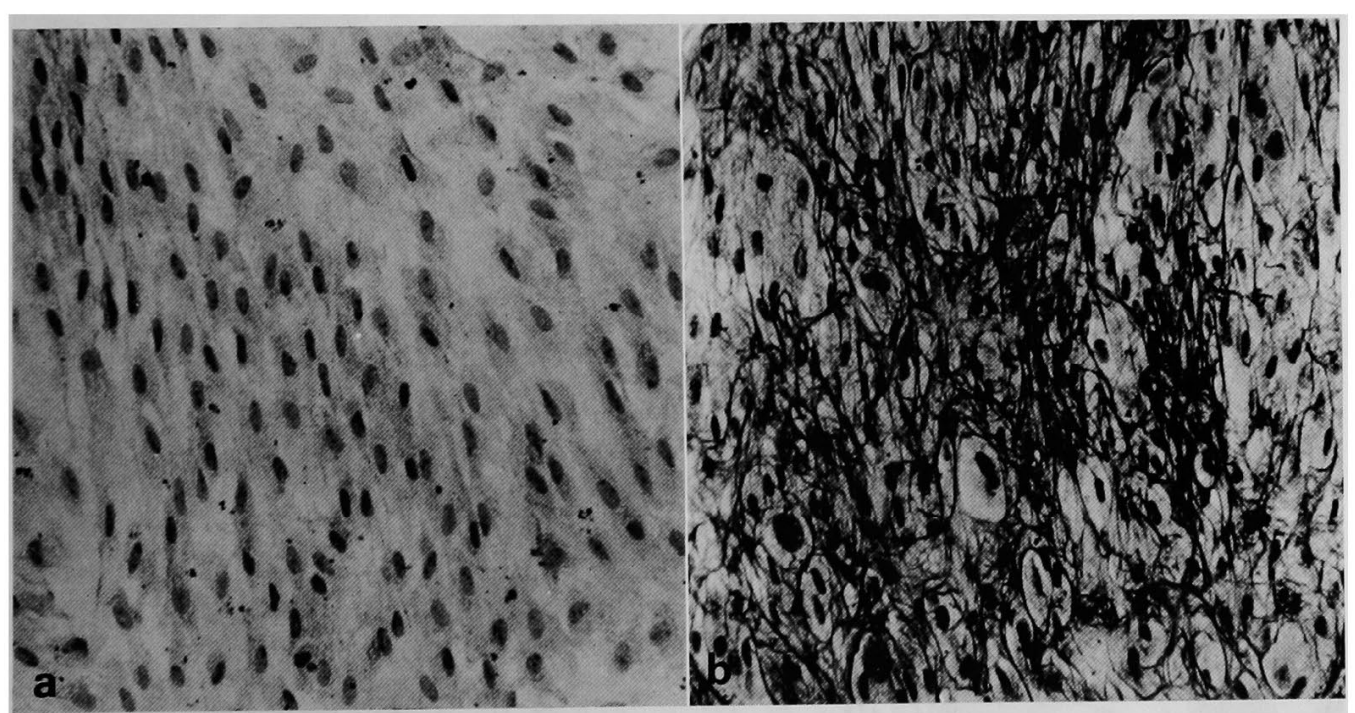

Fig. 7 Micrographs of fibroblast cultures in MEM-5\% medium with and without ascorbic acidsupplementation, stained by silver impregnation. a: 9-day-old culture with ascorbic acid deficiency, showing absence of fibers in the cell sheet. b: 3-day-old culture receiving ascorbic acid $(50 \mu \mathrm{g} / \mathrm{ml})$. Abundant and thicker collagen fibers have overgrown the cell sheet. $a$ and $b, \times 150$. 


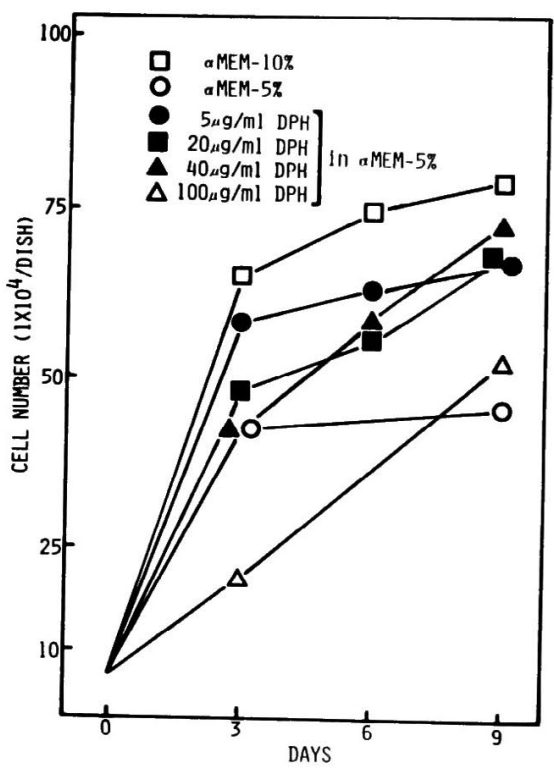

Fig. 8 Effect of various concentrations of diphenylhydantoin (DPH) on fibroblast proliferation.
ていることが推測された。

$\alpha \cdot \mathrm{MEM}$ 培地での線維形成は血清濃度依存性が みられず， 1-10\%血清群でほぼ同様の傾向を示 した（Fig. 6）。培養 1 日で明らかな線維形成が始 まり，増殖対数期を通して線維形成 index が上 昇した。この結果は線維形成条件と環境が整え ば，増殖誘導期と対数期でも線維形成が行われる ことを示す興味ある結果である。長期間培養で線 維形成 index が高まらないのは，線維形成と同時 に形成されたコラゲン線維の消化・分解が起って いるためと考えられる。

2.アスコルビン酸の影響

細胞増殖率と同様に，線維形成における $\alpha$ MEM 培地と DM-160培地の大きな差異は, ア スコルビン酸含有量によることが推測された。ア スコルビン酸を全く含有しない Eagle の MEM 培地では明らかなコラゲン線維形成は認められな かったが, $50 \mu \mathrm{g} / \mathrm{ml}$ のアスコルビン酸添加により $\alpha-\mathrm{MEM}$ 群とほぼ同様の細胞増殖と線維形成が観

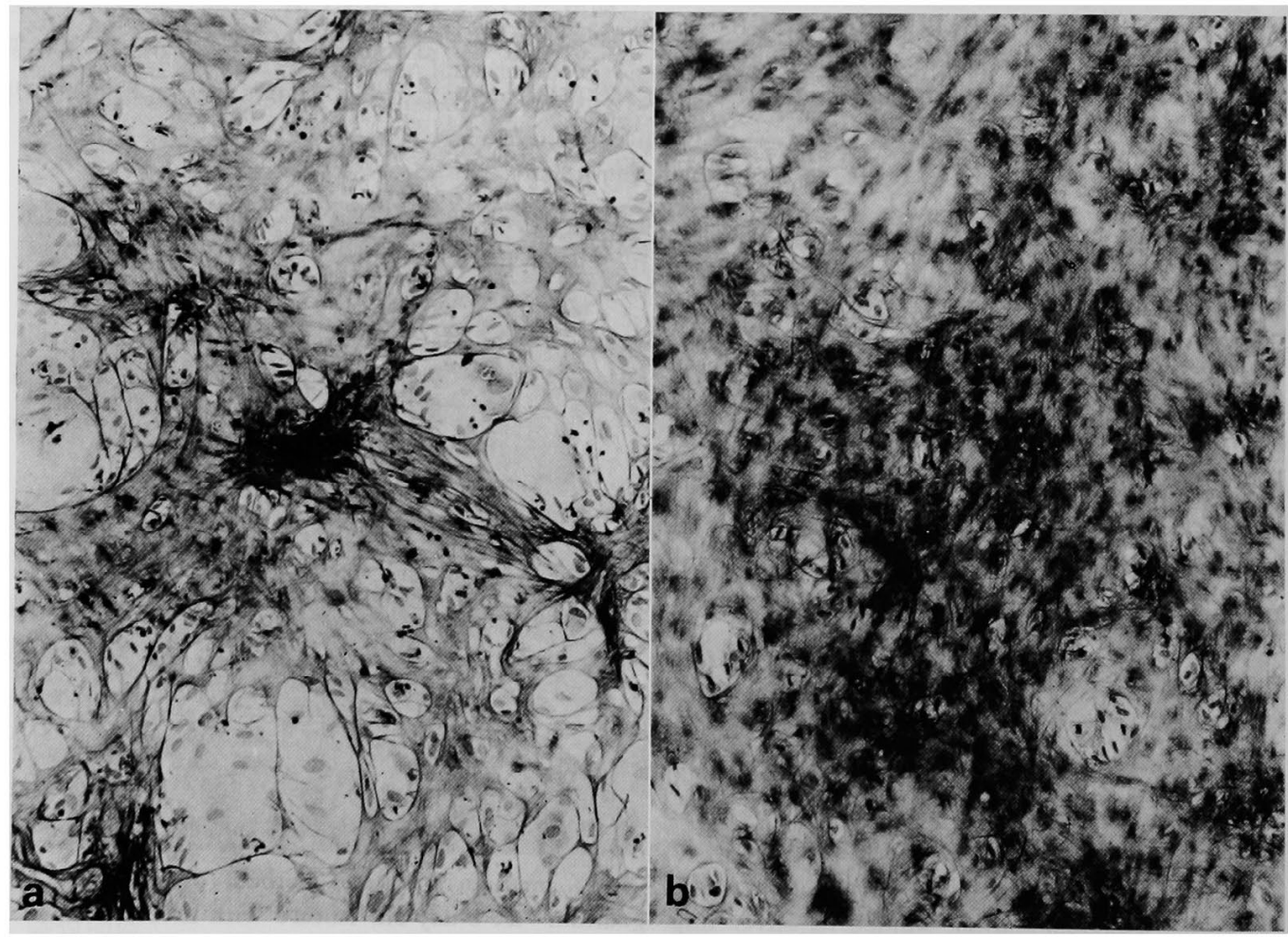

Fig. 9 Micrographs of fibroblast cultures in $\alpha$ MEM-5\% medium with and without DPH for 14 days, stained by silver impregnation. a : Non DPH-supplemented culture. b: DPH $(5 \mu \mathrm{g}$ $/ \mathrm{m} l)$-supplemented culture. Note the increase in fibers. $\mathrm{a}$ and $\mathrm{b}, \times 150$. 
察された。また，電顕観察からも DM 培地と MEM 培地群の細胞は横紋構造を有するコラゲン 原線維は形成しておらず，主に弾性線維の microfibrils を形成していた。これに対して， $\alpha$-MEM 培地と MEM 培地にアスコルビン酸 $(50 \mu \mathrm{g} / \mathrm{m} l)$ 添加群の細胞は， $64 \mathrm{~nm}$ の横紋を有するコラゲン 原線維を形成し，形成した基質線維束に埋め込ま れていた。これらの結果は, Schafer 等 ${ }^{3)}$ と Levene 等 ${ }^{10)}$ の結果によく一致し, アスコルビン酸 1 $\mu \mathrm{g} / \mathrm{m} l$ 含有の $\mathrm{DM}$ 培地では, アスコルビン酸欠 そ状態であることを示している。

培養液中のアスコルビン酸は，プロトコラゲン のプロリン水酸化酵素とリジン水酸化酵素を活性 化し，コラゲン分子中のプロリンとリジンを水酸 化する ${ }^{5,9,13)}$ 。コラゲン分子の 分泌量9) と変性温 度 $^{15)}$ は八イドロオキシプロリン含量に比例し上昇 するので, アスコルビン酸存在下では, 変性温度 の高い安定なコラゲン分子が多量に分泌されると 考えられる。また，ハイドロオキシリジンによる コラゲン分子間の架橋形成は, 塩や酸に不溶性の コラゲンを増加させることが知られている さらに最近，アスコルビン酸のプロコラゲン mRNA への直接作用を示唆する報告もある。こ のように，アスコルビン酸はプロコラゲン分子中 のプロリンとリジンの安定性と不溶化に 関与し, コラゲンヘリックスの安定化と不溶化, さらに分 泌を促進し，細胞外でのコラゲン線維形成に作用 したと考えられる。さらに形成された基質線維は 細胞接触による増殖阻止に影響し, 増殖率に変化 をもたらしたと思われる。

アスコルビン酸は溶液中では不安定であり， $\alpha-$ アミノ酸と共存すると容易に不可逆的分解を受け $3^{20)}$ 。培養液中のアスコルビン酸は $37^{\circ} \mathrm{C}, 24$ 時間 で 88-99\% が分解されていると報告されてい る5)。しかし，アスコルビン酸添加群では活発な コラゲン線維形成が観察され，アスコルビン酸の 分解と線維形成との関係については, さらに詳細 な生化学的・形態学的研究が必要である。他方, アスコルビン酸はプロリンとリジンの水酸化酵素 の特異的な因子ではなく，他の還元剤によっても 代用できることも明らかにされている ${ }^{11}$ 。アスコ ルビン酸欠乏状態での長期培養における線維形成
は, 血清中の少量のアスコルビン酸や他の還元因 子とその蓄積，それに低いコラゲン生成量とが作 用して，安定なコラダンが合成されたことによる ものと考えられる。

プロリン水酸化酵素活性に作用するアスコルビ ン酸濃度は，一般には25-50 $\mu \mathrm{g} / \mathrm{m} l$ とされている が，ある種の線維芽細胞では約 $0.08 \mu \mathrm{g} / \mathrm{m} l$ で有効 との報告もある ${ }^{9)}$ 。このよなアスコルビン酸の 細胞による有効浱度の差異と不安定性が，コラゲ ン線維形成におけるアスコルビン酸作用の結果の 不一致の理由の一つと考えられる。

3. $\mathrm{DPH}$ の影響

ダイランチン性歯肉肥大の発症原因としては, 口腔内の局所的因子が強く作用しているとの考え が強い。またこの発現と進行にはアレルギー反 応, 血管や血液の変化, あるいは内分泌異常によ るものとする全身的な因子を無視することができ ないことも報告されている。しかし一方, DPHに よって線維芽細胞の増殖が活性化され ${ }^{16-19)}$, 組織 像においてもコラゲン線維の増殖を認める報告も 多い。我々の結果でも，DPH は細胞増殖と線維 形成の両面での促進効果がみられた。他方 Goultschin \& Shoshan ${ }^{21}$ は DPH のコラゲン分解の 抑制による結果, 線維形成量が増加したと報告し ている。また Hassell 等 ${ }^{22)}$ はヒト正常歯肉由来 の培養線維芽細胞に対して DPH が無効であった ことを報告している。細胞の DPH 感受性の差 異が, 報告される実験結果の不一致の要因とも考 えられる。

DPH 感受性線維芽細胞では, DPH が細胞の 代謝過程に何んらかの影響を与えていることは明 らかと思われる。

\section{結 論}

ラット背側皮膚由来の線維芽細胞を用いて，細 胞の増殖とコラゲン線維形成に対する培地, 血清 濃度，アスコルビン酸と DPH の影響を検討し て, 以下の結果を得た。

1. 細胞增殖率は $\alpha$-MEM 培地（アスコルビ ン酸含有量 $50 \mu \mathrm{g} / \mathrm{m} l$ ) と DM-160培地（アスコル ビン酸含有量 $1 \mu \mathrm{g} / \mathrm{m} l$ ) で共に，血清浱度依存性 を示した。しかし，この増殖率は $\alpha$-MEM 培地 
ではより高かった。

2. コラゲン線維形成は, 細胞の增殖対数期と 定常期を通して認められた。しかし，培地により その形成状態は大いに暴った。 $\alpha$-MEM 培地では, 線維形成率は血清依存性が認められず，形成量は 高く, 定常期に入るとプラトーに達した。しかし, DM-160 培地では，線維形成率は低く，長期培養 （3 週以後）で初めて形成量の増加がみられた。

3. 培養線維芽細胞でのコラゲン線維形成には アスコルビン酸を必要とし，その添加は有効であ
った。 $\alpha$-MEM 培地と DM-160培地における， 線維形成の大きな差異は，アスコルビン酸含有量 の差によるもので, DM-160培地の $1 \mu \mathrm{g} / \mathrm{m} l$ アス コルビン酸では，その欠乏状態にあることが明ら かとなった。

4. DPH は細胞増殖とコラゲン線維形成の両 者を促進した。しかし，DPH の作用機序につい ては,さらに詳細な研究が必要と思われる。 本研究の一部は, 文部省科学研究費補助金（課題番号 58480368) による。

抄録: ラット皮虐由来の線維芽細胞を用いて, 細胞増殖とコラゲン線維形成に対する培地, 血清濃度, ア スコルビン酸とジフェニルヒダントイン（DPH）の影響を形態学的に研究した。

細胞増殖率は， $\alpha$-MEM 培地と DM-160培地で共に，血清濃度依存性を示した。しかし， $\alpha$-MEM 培地で の増殖率は, DM-160培地のものより高かった。 $\alpha$-MEM 培地では, 線維芽細胞は培養 1 日 で渡銀される線 維を形成し，増殖対数期と定常期を通して細胞外にコラゲン線維を形成・蓄積した。DM-160 培地での線維 形成率は培養 3 週まで低く，その後，コラゲン線維量の増加がみられた。

DM-160培地（アスコルビン酸含有量 $1 \mu \mathrm{g} / \mathrm{m} l$ ) の線維芽細胞は, $\alpha \cdot \mathrm{MEM}$ 培地（アスコルビン酸含有量 $50 \mu \mathrm{g} / \mathrm{m} l)$ の細胞に比べて，アスコルビン酸欠乏状態であった。これらアスコルビン酸欠乏状態では，典型 的な64 nm 横紋を持つコラゲン線維形成は阻害され,横紋のない, 細線維と microfibrils が形成されていた。 これらの結果は，この線維芽細胞はコラゲン線維形成にアスコルビン酸を必要とすることを明らかにした。 培養線維芽細胞への DPH の添加は, 細胞増殖とコラゲン線維形成の両者を促進した。

\section{文献}

1) Green, H. and Goldberg, B. : Kinetics of collagen synthesis by established mammalian cell lines. Nature 200 : 1097-1098, 1963.

2) Goldberg, B. and Green, H.: An analysis of collagen secretion by established mouse fibroblast lines. J. Cell Biol. 22 : 227-258, 1964.

3) Schafer, I. A., Silverman, L., Sullivan, J. C. and Robertson, W. van B.: Ascorbic acid deficiency in cultured human fibroblasts. J. Cell Biol. 34 : 83-95, 1967.

4) Layman, D. L., Narayanan, A. S. and Martin, G. R. : The production of lysyl oxidase by human fibroblasts in culture. Arch. Biochem. Biophys. 149 : 97-101, 1972.

5) Peterkofsky, B.: The effect of ascorbic acid on collagen polypeptide synthesis and proline hydroxylation during the growth of cultured fibroblast. Arch. Biochem. Biophys. 152 : 318-328, 1972.

6) Levene, C. I., Shoahan, S. and Bates, C. J. : The effect of ascorbic acid on the crosslinking of collagen during its synthesis by cultured 3T6 fibroblasts. Biochim. Biophys. Acta 257 : 384-388, 1972.
7) Levene, C. I., Bates, C. J. and Bailey, A. $\mathrm{J}$.: Biosynthesis of collagen cross-links in cultured 3T6 fibroblast ; Effect of lathyrogens and ascorbic acid. Biochim. Biophys. Acta 263 : 574-584, 1972.

8) Levene, C. I. and Bates, C. J.: Ascorbic acid and collagen synthesis in cultured fibroblasts. Ann. N. Y. Acad. Sci. 258 : 288-306, 1975.

9) Blank, T. J. J. and Peterkofsky, B.: The stimulation of collagen hydroxylation in chick embryo fibroblast. Arch. Biochem. Biophys. 171 : 259-267, 1975.

10) Levene, C. I., Ockleford, C. P. and Barber, C. L.: Scurvy ; a comparison between ultrastructural and biochemical changes observed in cultured fibroblasts and the collagen they synthesise. Virchows Arch. B Cell Path. $23: 325-338,1977$.

11) Chen, K. H., Evans, C. A. and Gallop, P. M. : Prolyl and lysyl hydroxylase activation and cofactor specificity in young and senescent WI-38 fibroblast cultures. Biochem. Biophys. Res. Commun. 74 : 1631-1636, 1977.

12) Tajima, S. and Pinnell, S. R. : Regulation of collagen synthesis by ascorbic acid, Ascor. 
bic acid increases type I procollagen mRNA. Biochem. Biophys. Res. Commun. 106 : 632$637,1982$.

13) Sodek, J., Feng, J., Yen, E. H. K. and Melcher, A. H.: Effect of ascorbic acid on protein synthesis and collagen hydroxylation in continuous flow organ cultures of adult mouse periodontal tissues. Calcif. Tiss. Int. 34 : 408-415, 1982.

14) Chen-Kiang, S., Cardinale, G. J. and Udenfriend, S.: Homology between a prolyl hydroxylase subunit and a tissue protein that crossreacts immunologically with the enzyme. Proc. Natl. Acad. Sci. USA 74 : 4420-4424, 1977.

15) Rosenblom, J. and Harsch, T. : Hydroxyproline content determines the denaturation temperature of chick tendon collagen. Arch. Biochem. Biophys. 158 : 478-484, 1973.

16) Shafer, W. G.: Effect of Dilantin Sodium on growth of human fibroblast-like cell cultures. Proc. Soc. Exp. Biol. 104 : 198-201, 1960.
17) Shafer, W. G.: Effect of Dilantin Sodium analogues on cell proliferation in tissue cul. ture. Proc. Soc. Exp. Biol. 106 : 205-207, 1961.

18) Shafer, W. G.: Effect of Dilantin Sodium on various cell lines in tissue culture. Proc. Soc. Exp. Biol. 108 : 694-696, 1961.

19) Shafer, W. G.: Response of radiated human gingival fibroblast-like cells to Dilantin Sodium in tissue culture. J. Dent. Res. 44 : 671-677, 1965.

20）荒川信彦：アスコルビン酸とその関連化合物の 化学. (日本ビタミン学会編) ビタミン学II, p. 569-578, 化学同人, 東京, 1980.

21) Goultschin, J. and Shoshan, S. : Inhibition of collagen breakdown by diphenylhydantoin. Biochim. Biophys. Acta 631 : 188-191, 1980.

22) Hassell, T. M., Page, R. C., Narayanan, A. S. and Cooper, C. G.: Diphenylhydantoin (Dilantin) gingival hyperplasia: Druginduced abnormality of connective tissue. Proc. Natl. Sci. USA. 73 : 2909-2912, 1976. 